Submitted $12^{\text {th }}$ April 2021

Accepted 15 $5^{\text {th }}$ June 2021

\title{
CULINARY TOUR A LA MILLENNIALS (An Exploratory Study in Ubud)
}

\author{
Ni Ketut Wiwiek Agustina \\ Politeknik Pariwisata Bali, Indonesia \\ agustina.wiwiek@ppb.ac.id
}

\begin{abstract}
Ubud as one of the wellknown tourists' destinations in Bali Province, currently is developing the potency on culinary for tourism. Nowadays Ubud is also becoming the interests of millennial tourists to visit. Millenn ial tourists represent $27 \%$ of the global population or around 2 billion people. On average, they take 35 days of vacation each year with the typical of preferring experience the most. Therefore, this research is designed by exploratory study approach and the aims are to analyze and identify the interests of millennial tourists to visit Ubud for the purpose of tasting and enjoying culinary for the sake of tourism. Primary data is collected using semi-structured interviews with respondents as many as 30 (thirty) millennial visitors or tourists in Ubud. Through a descriptive method with a qualitative approach, this research explores millenials' thoughts and motivation of culinary tourists in Ubud. For the result, this study indicates millennials tourists' respondents have a high interest in culinary tours. Ubud is considered to offer a large selection of local culinary delights of good taste and quality; calm, comfortable, and nice view and atmosphere; and is a favorite destination for tourists. Sources of information about culinary tours in Ubud are recommendations from friends / relatives and social media. This study also includes exploratory observations regarding the food menu, location, facilities, and security in Ubud District. For wider perspectives on culinary tours a la millennials, further research is encouraged in other areas and interests.
\end{abstract}

Keywords: Culinary Tourism; Millennial Tourists; Food as culture.

\section{INTRODUCTION}

Currently tourism activities are not just a "rest and relax" or with the stereotype activities made to meet the needs of industrial workers. Tourism actors have also moved to youth which has created a segment of millennial tourists or millennial travelers. The United Nations World Tourism Organization (2016) defines millennial tourists as young travelers born between 1980 and 2000 . Millennial travelers typicals have an interest and curiosity about new, unique, and unusual things.

Millennial tourists travel more than any other demographic. Millennial tourists represent 27 percent of the global population or around 2 billion people. On average, they take 35 days of vacation each year, and they also have a hefty annual travel expense compared to other generations who are more conservative with their money (Sofronov, 2018). For them, the experience is more important than the real product. They prefer to spend more money on shopping, eating and drinking, than on lodging. Millennial tourists are also the fastest growing demographic covering 
around $20 \%$ of the market today and are expected to expand even more (Crown Verity, 2015).

Millennial tourists are key to the future of tourism for three reasons: the number of millennial tourists who travel today, the fact that their choices can lead to new habits in the tourism industry, and the anticipation that millennial tourists will continue to travel in the future (Cavagnaro, Staffieri, \& Postma, 2018). These are the things that tour operators, travel agents and the entire travel industry need to understand and consider. The behavior of millennial tourists is very influential for tourism products and also the development of tourism destinations globally.

Assistant Deputy for Cultural Tourism Development in the Guidebook for Culinary Tourism Development of the Ministry of Tourism (2019) categorizes cultural tourism products into three categories, namely cultural \& historical heritage tours, culinary \& shopping tours, and village \& city tours. The linkage between food and tourism has now developed, not only as a basic need for tourists, but has also been used to differentiate each tourist destination by creating a different and impressive atmosphere. This also plays a role in determining the identity of the destination. The Global Report on Food Tourism explains that there are many things that can trigger tourists to visit a cultural tourism destination on a culinary basis (The United Nations World Tourism Organization, 2017).

The term culinary tourism is often used to describe a form of tourism activity that emphasizes the relationship between hosts and guests through food as culture. Definitively, Horng and Tsai (2010) explained that culinary tourism activities are experiences or tourism activities related to food, in which cultural learning and knowledge of tourist destinations and their communities are facilitated. From the understanding and definition of culinary tourism, food is considered a medium used to gain cultural experiences. Horng and Tsai (2010) furthermore stated that culinary tourism is an experience of tourism-based tourism activities that are in harmony with food and culture, as well as the personal interests of tourists.

The development of culinary-based tourism is very relevant to the millennial trend that has been described previously, where currently food and culinary are no longer synonymous with mass tourism. According to Global Data (2018) the consumer survey Q3-2018, 27.6\% of global consumers think that the popularity of a destination in terms of food and drink is the factor that helps them decide where to stay on vacation. The Global Data survey also shows that millennials perceive local cuisine to be more influential when choosing travel destinations than other generations. So, providing a different experience about food is the main focus that travel service providers need to innovate on.

Almost all regions of Indonesia offer a variety of interesting culinary options. One of them is Ubud, Bali. According to The New Attribute Culinary Tour Book for Ubud Destinations (2016), Ubud's popularity as a culinary tourism destination is the result of travel and hard work that cannot be separated from Ubud's branding as a cultural tourism destination that dated back to the 1930s. Visits made by tourists to Ubud provide opportunities for local residents to develop local culinary delights such as chicken with rice and roast suckling pig. This food menu initially attracted local residents, local / domestic tourists, tourist guides and travel drivers. However, starting in the 1990s, local culinary delights began to attract the tastes and attention of foreign tourists. Since long time ago, Ubud has been known as a culture-based 
tourist destination. The new branding of Ubud as a culinary tourism is also included in the development or complement of the popular cultural tourism branding so far, because culinary is also a part of culture (Putra, 2016).

There are many culinary-based tourism activities that millennial tourists can experience in Ubud. Cooking with the locals, visiting food markets, tasting street food, and exploring the various restaurants in Ubud - from historic to modern and from family owned businesses to large restaurants - tourists can get a glimpse of the authenticity of Ubud itself, which in turn allows them to understand more on how Ubud and its cuisine have evolved over time. One of the culinary festivals that is in great demand by foreign millennial tourists is the Ubud Food Festival since 2015 (Ubud Food Festival, 2021). Seeing that the tourism industry is now dominated by the millennial generation where they are very close to the internet media, this research is designed to find out the interest of millennial tourists in culinary tour by exploratory study approach in Ubud, Gianyar-Bali.

\section{METHODOLOGY}

This research method uses qualitative methods, with an exploratory case study approach. Qualitative research is a scientific research method that aims to understand something or several phenomena with a natural social context. In conducting a study, this qualitative research must be based on the strong interaction of the researcher with the existing phenomena (Moleong, 2018). Exploratory research can be considered as a research approach used to formulate the problem of a phenomenon, where the solution or solution to the problem can raise other types of research, for example, descriptive or explanative. The purpose of exploratory research is to produce generalizations derived from inductive processes about the studied group, process, activity, or situation (Given, 2008).

The research technique uses two types of data, namely primary data and secondary data. According to Hasan (2002), Primary data is data obtained in the field, and collected by researchers directly. This primary data is in the form of notes from the results of interviews with informants \& parties related to this research, the results of observations at the research location, and data on visits in the Ubud area. The interviews that were conducted to collect primary data were semi-structured interviews. Semi-structured interviews were carried out by compiling a list of questions which were then developed based on the topic of the problem and related literature. Meanwhile, secondary data were collected from several literature studies such as articles on journals and scientific papers.

Respondents for this study are millennial tourists who visited Ubud. Purposive sampling technique is used in select the respondents. Purposive sampling is a sampling technique based on considerations and criteria that are formulated in advance (Sugiyono, 2012). In this case, the determination of the sample is based on observations in the field of millennial tourists who are in the culinary tourism area. As long as the desired information can be obtained and generated, there is no limit to the number of respondents in determining purposive sampling (Bernard, 2006). Therefore, the number of respondents in this study is limited to 30 respondents. According to Guest, Bunce, and Johnson (2006) and Krysik (2010) the process of interviewing respondents took place until data saturation was reached, and also no new information and information could be obtained. 
The entire interview process was carried out with the respondent's permission and consent, recorded in audio which then would be verbally transcribed. To find out the interest of millennial tourists in culinary tourism in Ubud, respondents were asked the following questions:

1. Explain the reason for your culinary tour in Ubud!

2. Tell me about the culinary tour in Ubud that you like the most!

3. Where did you get the information about culinary tours in Ubud?

4. Are you interested in coming back to Ubud for a culinary tour?

The model or flow of this research is as follows:

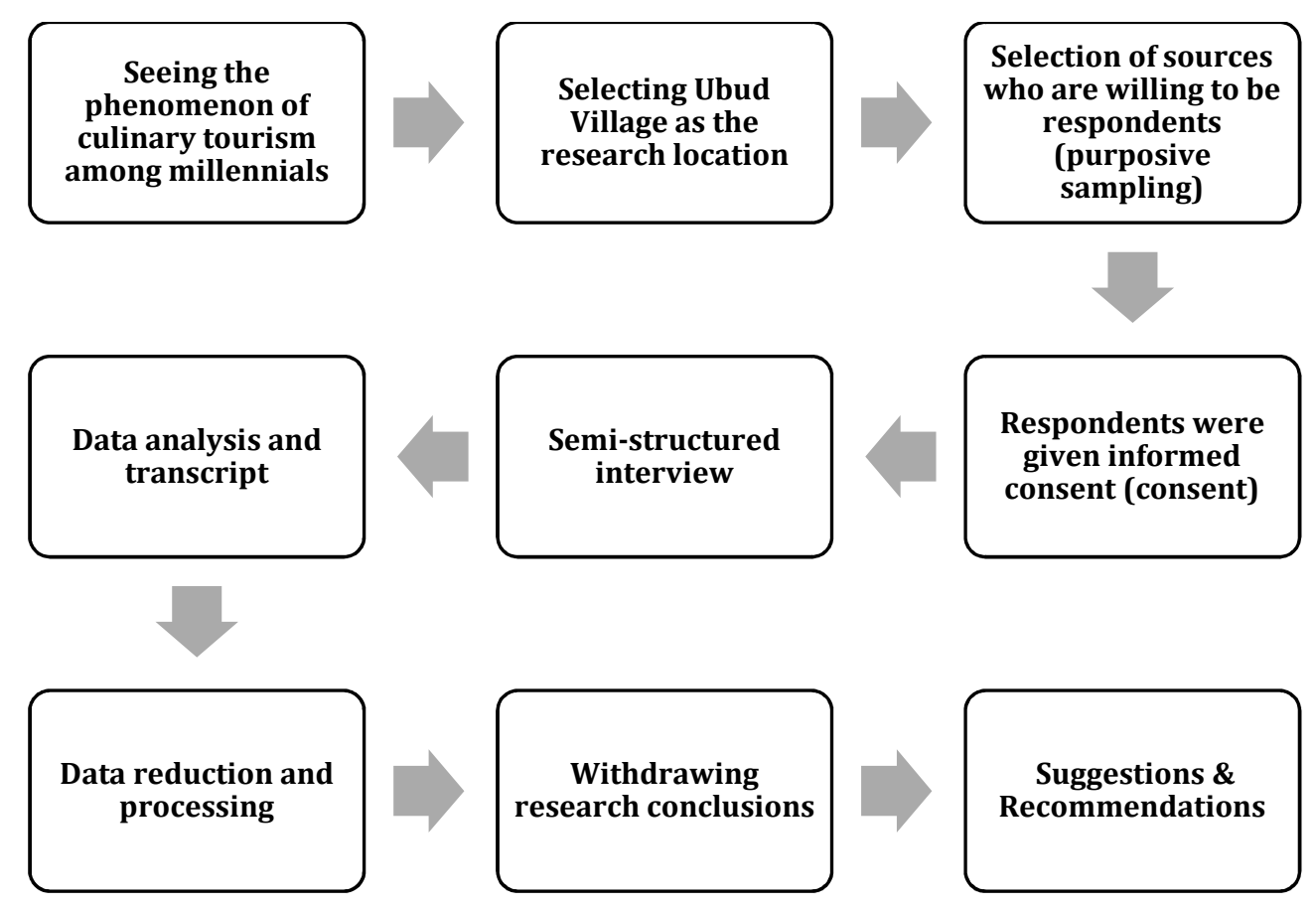

\section{RESULTS AND DISCUSSION}

Ubud is one of the sub-districts in Gianyar Regency. From a geographical perspective, the area of Ubud is estimated to be around $42.38 \mathrm{~km} 2$ or $11.52 \%$ of the area of Gianyar Regency. Ubud consists of eight villages: Kedewatan, Lodtunduh, Peliatan, Singakerta, Mas, Petulu, Sayan, and Ubud. Based on the Central Statistics Agency of Gianyar Regency (2018), the total population of Ubud is estimated to be around 72,290, consisting of 36,480 men (49.54\%), and 35,810 women (49.54\%). Ubud has become a tourist destination because of its culture and natural scenery. Equipped with beautiful natural rivers, rice fields and forests. In addition, Ubud is the center for cultural and artistic performances in Bali.

The purpose of this exploratory study is to obtain information about the interest of millennials in culinary tourism, especially culinary tours in Ubud Village. All respondents' statements are stated and quoted directly in the field. All data statements have been reduced and grouped based on the same theme or topic. 
Data reduction is the process of selecting and focusing attention on simplifying, abstracting, to transforming \& processing rough data obtained in the field. The results of data reduction are processed to form a more complete conclusion (Rijali, 2019).

Respondents from this study will then be given the initials R1, R2, R3, R4, etc. It aims to maintain the confidentiality of the respondents. A questionnaire and semi-structured interview were developed and conducted based on the relevant literature. All respondents from this exploratory research are millennials who have an interest in culinary tourism and experience culinary tours in Ubud.

\begin{tabular}{|c|c|c|c|c|}
\hline Initials & Gender & Age & Profession & Origin \\
\hline $\mathbf{R} 1$ & Man & 21 & College student & Denpasar \\
\hline $\mathbf{R 2}$ & Women & 20 & entrepreneur & Ubud \\
\hline $\mathbf{R 3}$ & Women & 19 & Student & Ambon \\
\hline R4 & Women & 21 & Student & Abiansemal \\
\hline R5 & Man & 23 & entrepreneur & Makassar \\
\hline R6 & Man & 22 & Graphic Desginer & Denpasar \\
\hline $\mathbf{R 7}$ & Man & 23 & Freelancers & Denpasar \\
\hline $\mathbf{R 8}$ & Women & 21 & Student & Jakarta \\
\hline R9 & Women & 21 & Student & Padang \\
\hline R10 & Man & 20 & Students & Padang \\
\hline R11 & Women & 21 & Student & Buleleng \\
\hline R12 & Women & 21 & Student & Klungkung \\
\hline R13 & Women & 20 & Student & Yogyakarta \\
\hline R14 & Man & 18 & Student & Banyuwangi \\
\hline R15 & Women & 20 & Student & Banyuwangi \\
\hline R16 & Man & 21 & Radio announcer & Gianyar \\
\hline R17 & Man & 20 & College student & Denpasar \\
\hline R18 & Man & 21 & College student & Badung \\
\hline R19 & Man & 19 & College student & Denpasar \\
\hline $\mathbf{R 2 0}$ & Women & 21 & $\begin{array}{l}\text { Pharmaceutical } \\
\text { Technical Staff }\end{array}$ & Denpasar \\
\hline R21 & Women & 20 & College student & Denpasar \\
\hline $\mathbf{R 2 2}$ & Man & 22 & College student & Gresik \\
\hline $\mathbf{R 2 3}$ & Women & 26 & Private employees & Padang \\
\hline R24 & Women & 20 & College student & Gianyar \\
\hline R25 & Man & 21 & College student & Denpasar \\
\hline R26 & Women & 22 & Student & Padang \\
\hline R27 & Women & 21 & Student & Bogor \\
\hline $\mathbf{R 2 8}$ & Man & 20 & College student & Tabanan \\
\hline R29 & Man & 19 & Freelancers & Tabanan \\
\hline R30 & Man & 20 & College student & Bangli \\
\hline
\end{tabular}

Table 1. Profile of Respondents

Based on semi-structured interviews with 30 respondents on March $7 \& 14$ and April 1, 2021, the following research results were obtained: 
Reasons and factors for visiting Ubud culinary tours

Several respondents gave statements regarding the reasons and factors that motivated them to take a culinary tour in Ubud. The reasons and factors are:

1. Local cuisine

The following are quotes from several respondents:

"The thing is that Ubud is famous for its local specialties like chicken, also the duck, and the Balinese spices." (R4)

"Because Ubud is still beautiful and there are many traditional culinary delights there." (R14)

2. Nice and photography worthy café

Statements such as:

"Because in Ubud there is a lot of food and there are lots of cute cafes." (R3)

"The place to eat is indeed aesthetic and photography worthy." (R22)

3. View and good ambience

"Nice view, comfortable atmosphere for eating, beautiful and not crowded." (R9)

"Ubud has a beautiful atmosphere so you can enjoy delicious food" (R20)

4. An affordable price

Other respondents also gave the following statements:

"Apart from various kinds of food, besides that it is also cheap." (R30)

"Because there are now many culinary tours that are delicious and affordable." (R25)

\begin{tabular}{|lll|}
\hline Reasons and Factors & Total & Percentage \\
\hline Local cuisine & 7 & $23.33 \%$ \\
\hline Photography worthy & 6 & $20 \%$ \\
\hline Great view and atmosphere & 10 & $33.33 \%$ \\
\hline Quality and price & 7 & $23.33 \%$ \\
\hline TOTAL & 30 & $100 \%$ \\
\hline
\end{tabular}

Table 2. Visit Factors

Based on the respondents' statements, the millennials tourists love having culinary tour at Ubud because most of the restaurants or café they visited had great green views. The restaurants or café at Ubud are also decorated and instagramworthy for most of the respondents. Views, beauty, and atmosphere are great aspects to be considered because they want their social media followers to be curious.

Some other respondents decided to visit Ubud and have culinary tour there because of its local cuisine and the quality of the food. When being interviewed, some of them want a unique and new taste sensation whenever they are on vacation, that's why they take local food and its quality into consideration.

Culinary tours in Ubud that have been tried

All respondents gave statements regarding culinary tours that have been tried in Ubud. Here are some excerpts:

1. Roast Suckling Pig 
"Babi guling, mixed rice" (R19)

2. Nasi Ayam Kedewatan

"Nasi Ayam Kedewatan, Warung Men Joel, Babi Guling Bu Oka, Umah Pizza, and the rest is a coffee shop." (R10)

3. Nasi Campur Men Juwel

"Nasi Campur Mek Juwel, Nasi Ayam Kedewatan and Babi Guling are great.(R7)

4. Fish Based Culinary

"... ordinary fried fish at Warung Mak Beng besides that there is a Babi Guling Bu Oka stall ..." (R1)

5. Duck Based Culinary

"Duck bengil, duck edge of rice fields." (R9)

6. Food Café

"Kayana Grilled Pork Ribs, Kakiang Garden Café, Good Pizza, etc" (R17)

\begin{tabular}{|c|c|c|}
\hline $\begin{array}{ll}\text { Ubud's } & \text { Culinary } \\
\text { Selection } & \end{array}$ & Tour Total & Percentage \\
\hline Roast Suckling Pig & 8 & $26.67 \%$ \\
\hline Nasi Ayam Kedewatan & 7 & $23.33 \%$ \\
\hline Duck & 5 & $16.67 \% \%$ \\
\hline Nasi Campur Men Juwel & 4 & $13.33 \%$ \\
\hline Fish & 3 & $10 \%$ \\
\hline Food Café & 3 & $10 \%$ \\
\hline TOTAL & 30 & $100 \%$ \\
\hline
\end{tabular}

Table 3. Ubud's Culinary Tour Selection

Based on the interview's results, millennial tourists have a big interest in famous local dishes in Ubud Bali. Most of them have roast suckling pig when visited Bali, and some of the restaurants mentioned are Warung Men Joel, Babi Guling Bu Oka, and Warung Babi Guling Pande Egi. The respondents visited these restaurants because the food is great, the price is okay, and those are some wellknown restaurants here in Ubud.

Besides that, Nasi Ayam Kedewatan seems to be pretty popular among millennial tourists. 7/30 respondents said that they had the best Balinese chicken rice there, and what's even more interesting for them is the price. Nasi Ayam Kedewatan offers affordable price and the ambience of the place is just great. But several respondents stated that they also visited the café to cool off and be in a new atmosphere because most places in Ubud are outdoor.

The source of information about culinary tour in Ubud All respondents gave a statement regarding the source of the information they got about culinary tour in Ubud. Here's an excerpt:

1. Social media such as Instagram, Tiktok, Facebook, etc.

"IG, Facebook." (R9)

"Instagram, Tiktok, mostly social media." (R10)

2. Friends \& Relatives 
"Most social media are the same recommended by my friends." (R3)

"Friends who live in Ubud." (R6)

\begin{tabular}{|lll|}
\hline Information Center & Total & Percentage \\
\hline Social media & 16 & $53.33 \%$ \\
\hline Friends / Relatives & 14 & $46.67 \%$ \\
\hline TOTAL & 30 & $100 \%$ \\
\hline
\end{tabular}

Table 6. Tourist Information Center

As shown in the table, the majority of millennial tourists got the information about Ubud's culinary from social media. The respondents said that they looked up the recommended restaurants from their mutual's instagram account, or official instagram accounts like@balifoodies,@thebaliguideline,@thebalibible, and many more. Most of the respondents admitted that they got curious about several restaurants based on their For Your Page section on Tiktok. The millennials described that they gained more information from the video because it contained the price, the address, and the overall review of all the food.

But not a few of the millennial tourists got the information from their friends/relatives. They would ask their relatives who live there or who have visited Ubud. The respondents stated that they would belive more in their closest relatives than the internet.

Recommended Ubud culinary tour to friends / relatives

\begin{tabular}{|lll|}
\hline Recommendation & Total & Percentage \\
\hline Yes & 28 & $93.33 \%$ \\
\hline Not & 2 & $6.67 \%$ \\
\hline & & \\
\hline TOTAL & 30 & $100 \%$ \\
\hline
\end{tabular}

Table 7. Recommended Ubud Culinary Tours

From the results of the interviews held, all respondents gave a statement that they would recommend a culinary tour of Ubud to friends / relatives. They would absolutely recommend their friend or relatives to try Ubud's culinary because they have never been let down by the food when visiting Ubud. While 2 out of thirty respondents stated that Ubud's dishes were okay, but they would recommend their closest friends to visit Ubud for its arts and culture instead.

Interest in coming back to Ubud for a culinary tour

\begin{tabular}{|lll|}
\hline Returning Interest & Total & Percentage \\
\hline Yes & 29 & $96.67 \%$ \\
\hline Not & 1 & $3.33 \%$ \\
\hline & & \\
\hline TOTAL & 30 & $100 \%$ \\
\hline
\end{tabular}

Table 8. Interest in Returning 
All interviewed respondents stated that they would visit Ubud again for a culinary tour. They all have great experience in Ubud, both in general and culinary. They would love to revisit Ubud to try new dishes recommendation or simply to taste their favorite food here in Ubud again. The millennials stated that Ubud is great for travelling because of the good food, the museums, the local markets, the temples, and so on.

Suggestions / criticisms of culinary tourism in Ubud

The majority of respondents gave suggestions / criticisms of culinary tourism in Ubud in terms of prices as follows:

"The price is too expensive, less populist" (R20)

"Overall is good, maybe the price should be adjusted slightly according to the pockets of students." (R8)

Several respondents also gave statements related to Ubud service, quality, and culinary choices, including:

1. Quality and service

"Keep up the quality." (R4)

"Service in each culinary place needs to be improved, especially in the Ubud area with a strong culture, cleanliness also deserves to be maintained." (R5)

2. Adding to local culinary

"I hope to get more local culinary specialties from Ubud Bali." (R10)

Regarding the Lanes / Parking Areas:

"Access made easy"(R11)

"... My suggestion is maybe the Ubud government needs to be aware of this potential and build more parking lots in the Ubud area, so that guests who visit will not have trouble finding parking when they want to explore culinary tourism in Ubud and of course, with sufficient parking space, the car is not parked. carelessly and the traffic just got smoother. "(R17)

\section{CONCLUSION}

Based on an exploratory study of millennials' interest in culinary tour in Ubud, it can be stated that the interest of the millennial generation in culinary tour is quite high. Culinary is one thing that is considered and in demand in the eyes of millennial tourists. When traveling, millennial tourists will usually find out about local culinary delights, explore their restaurants, taste special products / dishes, and get an overview of the traditions of local people in the culinary tourism destinations visited, so tourists can experience a unique and special experience.

The millennial tourists in Ubud discovered the information about Ubud's culinary from social media, friends, and relatives. It's shown that word of mouth is an effective way to promote a business and social media plays a big role as well. The most used social media for the millennials to find out about Ubud's culinary are Instagram and Tiktok. They would love to see some reviews and menus first before actually went there. This could be a big note to all restaurants or cafes to strengthen their promotion strategy.

According to the millennial respondents, their highest interest in culinary tour is good local food with good quality. Local culinary in Ubud favored by millennials is babi guling, bengil duck, and chicken mixed rice. These findings support the 
theory that millennials do love new things and have a lot of curiousity (The United Nations World Tourism Organization, 2016). The millennials also favor the ambience that Ubud has. They find Ubud to have nice green view, aesthetic decorations, and calm \& comfortable vibe. Several other things that are also taken into consideration for millennials in a culinary tour are aspects of price, aspects of service \& quality, and menu variations.

Overall, the millennial generation is satisfied with the culinary tourism in Ubud. All respondents, which are millennials, gave statements that they were interested in coming back to Ubud for a culinary tour and would recommend culinary tour to friends and relatives. It is also realized that the development of culinary tour is also supported by the development of social media, economic development, and increased understanding of traditional cultural heritage.

The limitation in this study is that the research subjects are only millennials around the village of Ubud and it is not certain that the results will be the same if the research is carried out in other areas on a larger scale. This research can be used as a reference for further research at different levels, in different parts of Bali, as well as in other places. For further research, quantitative methods can be developed with a larger sample size and a wider area, for example across provinces or across countries.

\section{SUGGESTIONS / RECOMMENDATIONS}

Suggestions and input from respondents can be taken into consideration for culinary tourism managers, especially culinary tour in Ubud. Then culinary destinations can create experiences and market them through social media to attract millennials who like new experiences. Culinary destinations need to understand the importance of social media and see that the higher the activity on social media, the greater their chances of finding culinary opportunities. Local dishes and food can be uploaded in their marketing materials. Millennials who are attracted to these culinary destinations are more likely to post their experiences on social media.

\section{REFERENCES}

Asisten Deputi Pengembangan Wisata Budaya. (2019). Pedoman Pengembangan Wisata Kuliner. Jakarta: Kementerian Pariwisata Republik Indonesia.

Badan Pusat Statistik Kabupaten Gianyar. (2018). Sosial dan Kependudukan. Retrieved from gianyarkab.bps.go.id website: https://gianyarkab.bps.go.id/publication/2018/09/26/fd0fbdbf58364b6539d4a 4da/kecamatan-ubud-dalam-angka-2018.html

Bernard, H. R. (2006). Research Methods in Anthropology: Qualitative and Quantitative Approaches. Lanham: AltaMira Press.

Cavagnaro, E., Staffieri, S., \& Postma, A. (2018). Understanding Millennials' Tourism Experience: Values and Meaning to Travel as A Key For Identifying Target Clusters for Youth (Sustainable) Tourism. Journal of Tourism Futures, $4(1)$.

Crown Verity. (2015). The Millennials and Catering in the Hospitality \& Travel Industry. Retrieved from Crown Verity website: https://www.crownverity.com/the-millennials-and-catering-in-the- 
hospitality-travel-industry/

Given, L. M. (2008). The Sage Encyclopedia of Qualitative Research Methods. Swinburne: Swinburne University.

Global Data. (2018). Key Trends in Culinary Tourism.

Guest, G., Bunce, A., \& Johnson, L. (2006). How Many Interviews Are Enough. Field Methods for Sage Journals, 18(1), 59-82.

Hasan, M. I. (2002). Pokok-Pokok Materi Metodologi Penelitian dan Aplikasinya. Bogor: Ghalia Indonesia.

Horng, J.-S., \& Tsai, C.-T. (2010). Government websites for promoting East Asian culinary tourism: A cross-national analysis. Tourism Management, 31(1), 7485. https://doi.org/10.1016/j.tourman.2009.01.009

Krysik, J. L. (2010). Research for Effective Social Work Practice. New York: Routledge.

Moleong, L. J. (2018). Metodologi Penelitian Kualitatif. Bandung: Remaja Rosda Karya.

Putra, P. D. (2016). Wisata Kuliner Atribut Baru Destinasi Ubud. Denpasar: Jagat Press.

Rijali, A. (2019). Analisis Data Kualitatif. Alhadharah: Jurnal Ilmu Dakwah, $17(33), 81-95$.

Sofronov, B. (2018). Millennials: a New Trend for The Tourism Industry. Annals of Spiru Haret University, (3), 109-122.

Sugiyono. (2012). Memahami Penelitian Kualitatif. Bandung: Alfabeta.

The United Nations World Tourism Organization. (2016). Tourism Highlight 2016 Edition. Madrid: World Tourism Organization.

The United Nations World Tourism Organization. (2017). Global Report On Food Tourism. Madrid: World Tourism Organization.

Ubud Food Festival. (2021). Ubud Food Festival. Retrieved from Ubud Food Festival website: ubudfoodfestival.com/ubud-food-festival/ 